\title{
港湾内の土砂堆積傾向に及ぼす 浚渫範囲の影響に関する 3 次元数值解析 \\ A THREE-DIMENSIONAL NUMERICAL ANALYSIS ON SEDIMENT DEPOSITION TREND AND EFFECTIVE DREDGING AREA IN PORT
}

\author{
中村友昭 1 ・石原遼 $2 \cdot$ 水谷法美 $3 \cdot$ \\ 尾上幸一郎 $4 \cdot$ 藤永聖一 4 - 山田耕三 5 ・石川正紀 6 \\ Tomoaki NAKAMURA, Ryo ISHIHARA, Norimi MIZUTANI, \\ Koichiro OGAMI, Seiichi FUJINAGA, Kozo YAMADA and Masaki ISHIKAWA \\ 1 正会員 博 (工) 名古屋大学特任講師 高等研究院（干464-8601 名古屋市千種区不老町） \\ 2 学生会員 名古屋大学大学院工学研究科社会基盤工学専攻（†464-8603 同上） \\ 3 正会員 工博 名古屋大学教授 大学院工学研究科社会基盤工学専攻（同上） \\ 4 阪和興業株式会社 名古屋支社（干461-8614 名古屋市東区東桜 1-13-3) \\ 5 正会員 工修 日建設計シビル（†112-0004 東京都文京区後楽 1-4-27） \\ 6 工修 日建設計シビル（干112-0004 東京都文京区後楽 1-4-27）
}

\begin{abstract}
In a port located near a river mouth, sediment deposition can affect operations of a berth. In dredging the accumulated sediment, it is essential to determine an effective dredging area for reducing the total cost of maintaining the berth. In this study, numerical simulations are carried out using a two-way coupled fluid-sediment interaction model to determine an effective dredging area near a berth of Nagoya Port, Japan. For validation, the model is applied to the current seabed topography. It is found that the model predicts reasonably well seabed profile change measured in field surveys. To determine the most effective dredging area, the model is applied to seabed topographies with several patterns of dredging area. The results show that sediment deposition in the dredging area depends on the size and surrounding slope of the dredging area, and suggest that it is necessary to assess flow fields and resulting seabed profile evolution in determining the most effective dredging area.
\end{abstract}

Key Words : Sediment deposition, dredging, port, berth, numerical analysis, fluid-sediment interaction

\section{1. 緒言}

河口に位置する港湾では，河川から流入した土砂 が堆積し, 航路やバースの水深が十分に確保できな くなることがある.そこで，この堆積した土砂を取 り除く浚渫作業が定期的に行われている. しかし， 土砂の堆積が生じにくく早急な浚渫が求められてい ない場所では，コストの問題もあり浚渫作業の頻度 はあまり高くない。このような場所で浚渫が必要に なった際には, 浚渫を必要最低限の範囲に限れば浚 渫自体に要するコストは抑えられるものの，浚渫範 囲を広くすることで必要な水深をより長期に渡って 確保できるのであれば，結果的には浚渫範囲を広く した方が将来的なトータルコストが抑えられると考 えられる。一方, 浚渫を行うと海底地形が急激に変 化するために，周辺の流動場とそれに伴う土砂の移 動特性も変化することから, 浚渫範囲の評価には流
動場と地形変化の相互作用を考慮した手法の使用が 望ましい。本研究では，バースに土砂が堆積し，必 要な水深の確保が困難になっている名古屋港の岸壁 を対象に，流動場と地形変化の相互作用を解析でき る 3 次元数值計算モデルを用いて浚渫範囲の違いに よる流動場と地形変化の特性を明らかにするととも に, それに基づいて効果的な浚渫範囲の検討を行う。

\section{2. 数値計算モデルの概要}

本論では，中村・水谷 ${ }^{1)}$ の開発した流体・構造・ 地形変化の 3 者間の相互作用を解析できる 3 次元数 值計算モデルを用いて解析を行った。同モデルは， 以下に述べるメインソルバーと 3 つのモジュールか ら構成されている。メインソルバーは，構造物の移 動や地形変化を取り扱えるようにした透過性材料の 
間隙内部を含む全気液相の非圧縮性粘性流体に適用 可能な連続式と Navier-Stokes（NS）方程式に基づく LES（Large-Eddy Simulation）である（Extended NS Solver；XNS）。その XNS には，気液界面を追跡す る VOF (Volume of Fluid) 法を改良した MARS (MultiInterface Advection and Reconstruction Solver) ${ }^{2}$ に基づ くモジュール (VOF Module ; VFM), 構造物の運動 を解析する体積力型埋め込夕境界法に基づく埋め込 み境界モジュール (Immersed Boundary Module;IBM)， 浮遊砂の巻き上げ, 移流拡散, 沈降の各輸送過程を 考慮して浮遊砂濃度を解析し, 掃流砂と浮遊砂の輸 送に伴う地形変化を追跡する底質輸送モジュール

(Sediment Transport Module; STM) が，XNS との 相互作用を考慮できるように Two-Way カップリン グ手法により組み込まれている. 同モデルの妥当性 は，これまでに一様流や砕波帯での漂砂現象などを 対象に検証されている. なお，本論では構造物の移 動は取り扱わないことから，IBM は使用しなかった。 以下，XNS，VFM，STMの概要を説明する.

\section{（1）拡張 Navier-Stokes ソルバー(XNS) と VOF モジ ユール (VFM) の概要}

XNS と VFM は, 以下の連続式, NS 方程式, VOF 関数 $F$ の移流方程式から構成されている.

$$
\begin{gathered}
\partial\left(m v_{j}\right) / \partial x_{j}=q^{*} \\
\left\{m+C_{A}(1-m)\right\} \frac{\partial v_{i}}{\partial t}+\frac{\partial\left(m v_{i} v_{j}\right)}{\partial x_{j}}=-\frac{m}{\hat{\rho}} \frac{\partial p}{\partial x_{i}}+m g_{i}+ \\
\frac{m}{\hat{\rho}}\left(f_{i}^{s}+R_{i}+f_{i}^{o b}\right)+\frac{1}{\hat{\rho}} \frac{\partial}{\partial x_{j}}\left(2 m \hat{\mu} D_{i j}\right)+\frac{\partial}{\partial x_{j}}\left(-m \tau_{i j}^{a}\right)+Q_{i}+m \beta_{i} \\
m \partial F / \partial t+\partial\left(m v_{j} F\right) / \partial x_{j}=F q^{*}
\end{gathered}
$$

ここで, $v_{i}$ は実流速べクトル, $p$ は圧力, $g_{i}$ は重力加 速度ベクトル $\left(=\left[\begin{array}{lll}0 & 0 & -g\end{array}\right]^{\mathrm{T}} ; g\right.$ は重力加速度 $), \hat{\rho}$ は 流体の密度 $\left(=F \rho_{w}+(1-F) \rho_{a} ; \rho_{w}, \rho_{a}\right.$ はそれぞれ 水之空気の密度 $), \hat{\mu}$ は流体の粘性係数 $\left(=F \mu_{w}+(1\right.$ -F) $\mu_{a} ; \mu_{w}, \mu_{a}$ はそれぞれ水之空気の粘性係数),$m$ は空隙率, $C_{A}$ は付加質量係数, $f_{i}^{s}$ は CSF (Continuum Surface Force） モデルに基づく表面張力， $R_{i}$ は透過 性構造物による線形・非線形抵抗力ベクトル ${ }^{3)}, f_{i}^{o b}$ は流体・構造間に作用する相互作用力ベクトル， $D_{i j}$ はひずみ速度テンソル $\left(=\partial v_{i} / \partial x_{j}+\partial v_{j} / \partial x_{i}\right), \tau_{i j}{ }^{a}$ は DTM（Dynamic Two-Parameter Mixed Model）に基づ く乱流粘性テンソルの非等方成分, $q^{*}$ は単位時間あ たりの造波ソース強度， $Q_{i}$ は造波ソースベクトル， $\beta_{i}$ は減衰領域における減衰係数べクトル $\left(=\left[\begin{array}{ll}0 & 0\end{array}\right.\right.$ $-\beta w]^{\mathrm{T}} ; \beta$ は減衰係数）であり, $R_{i}$ は

$$
R_{i}=-\frac{12 C_{D 2} \hat{\mu}(1-m)}{m d_{50}^{2}} v_{i}-\frac{C_{D 1} \hat{\rho}(1-m)}{2 m d_{50}} v_{i} \sqrt{v_{j} v_{j}}
$$

で与えられる。ただし， $C_{D 2}, C_{D 1}$ はそれぞれ線形， 非線形抵抗力係数, $d_{50}$ は透過性材料の中央粒径であ る. 以上の詳細は中村・水谷 ${ }^{1)}$ を参照されたい.

\section{（2）底質輸送モジュール（STM）の概要}

STM は, 地形変化を計算する底質の質量保存式, Roulund $5^{4)}$ を参考に構築されている掃流砂量と斜 面の崩壊を計算する掃流砂輸送モデル，浮遊砂濃度 を計算する浮遊砂輸送モデルから構成されている.

\section{a）底質の質量保存式}

底質の質量保存式は次式で表される。

$$
\frac{\partial z_{s}}{\partial t}+\frac{1}{1-m}\left(\frac{\partial q_{x}}{\partial x}+\frac{\partial q_{y}}{\partial y}+p_{N}+q_{z b}^{s}\right)=0
$$

ここで， $z_{s}$ は基準面からの底面の高さ， $q_{x}$ と $q_{y}$ はそ れぞれ $x, y$ 軸方向の掃流砂量, $p_{N}$ は底質の巻き上げ 関数, $q_{z b}^{s}$ は底面での $z$ 軸方向の沈降による浮遊砂輸 送フラックスである。

\section{b) 掃流砂輸送モデル}

掃流砂量 $q_{x}, q_{y}$ の算出には, 単位幅, 単位時間当 たりの $i$ 軸方向の掃流砂量 $q_{i}$ が底質粒子の平均輸送 速度の $i$ 方向成分 $v_{b i}$ に比例するとした掃流砂量式

$$
q_{i}=\pi d_{50} p_{E F} v_{b i} / 6
$$

が用いられている。ここで, $p_{E F}$ は掃流形態で移動す る底質粒子の割合であり，次式で与えられる。

$$
p_{E F}= \begin{cases}0 & \left(\tau_{*}<\tau_{*_{c}}\right) \\ 6\left(\tau_{*}-\tau_{*_{c}}\right) / \pi \mu_{d} & \left(\tau_{*} \geq \tau_{*_{c}}\right)\end{cases}
$$

ここで, $\mu_{d}$ は底質粒子の動摩擦係数, $\tau_{*}$ は Shields 数, $\tau_{*}$ は斜面での限界 Shields 数である. また, 式(6)の $v_{b i}$ は掃流形態で移動する底質粒子 1 個に作用する力 の釣り合い

$$
\begin{gathered}
F_{D} \cos \Psi_{1}+W \sin \beta \cos (\alpha-\Psi)=\mu_{d} W \cos \beta \\
F_{D} \sin \Psi_{1}=W \sin \beta \sin (\alpha-\Psi)
\end{gathered}
$$

および

$$
\begin{gathered}
v_{r} \sin \Psi_{1}=C_{v f} v_{f} \sin \Psi \\
v_{r} \cos \Psi_{1}+v_{b}=C_{v f} v_{f} \cos \Psi
\end{gathered}
$$

から求められる。ここで, $v_{b}$ は $v_{b i}$ の大きさ， $C_{v f} v_{f}$ は底質粒子に作用する流速の大きさ（v の大きさ, $C_{v f}$ は $v_{f}$ の係数) , $v_{r}$ は $v_{b}$ に対する底質粒 子の位置での相対速度の大きさ， $\alpha$ は斜面下向きに 対する $v_{f}$ の方向, $\beta$ は斜面の傾斜角, $\Psi$ は $v_{b}$ に対寸 る $v_{f}$ の方向, $\Psi_{1}$ は $v_{b}$ に対する $v_{r}$ の方向, $W$ は底質 粒子の水中比重, $F_{D}$ は底質粒子に作用寸る抗力であ り, $v_{f}$ は次式から求められる.

$$
\begin{aligned}
& v_{\text {surf }} / v_{f}=2 \int_{0}^{z^{+}} 1 /[1+ \\
& \left.\sqrt{1+4 \kappa^{2}\left(z^{+}+\Delta z^{+}\right)^{2}\left[1-\exp \left\{-\left(z^{+}+\Delta z^{+}\right) / A\right\}\right]^{2}}\right] d z^{+}
\end{aligned}
$$

ここで， $v_{\text {surf }}$ は底面から微小距離 $z^{+}\left(=z_{\text {surf }} v_{f} / v_{w}\right.$; $v_{w}$ は水の動粘性係数）だけ上方での流速， $\kappa^{\prime}$ は Kármán 係数, $A$ は van Driest 型減衰係数であり, $k_{s}^{+}$ を粗度 Reynolds 数 $\left(=k_{s} v_{f} / v_{w} ; k_{s}\right.$ は等価砂粗度）と すると， $\Delta z^{+}$は次式で与えられる。

$$
\Delta z^{+}=0.9\left\{\sqrt{k_{s}^{+}-k_{s}^{+} \exp \left(-k_{s}^{+} / 6\right)}\right\} \quad\left(4.535<k_{s}^{+}<2000\right)
$$




\section{c）浮遊砂輸送モデル}

浮遊砂の質量保存式を以下に示寸.

$$
m \partial C / \partial t+\partial\left(q_{j}^{C}+q_{j}^{D}+q_{j}^{S}\right) / \partial x_{j}=0
$$

ここで，C は浮遊砂濃度， $q_{i}^{c} ， q_{i}^{D}, q_{i}^{s}$ はそれぞれ 移流, 拡散, 沈降による浮遊砂輸送フラックスであ る。底面の境界条件として, Nielsen ら ${ }^{5}$ に倣って, 底面での $z$ 軸方向の拡散による浮遊砂拡散フラック ス $q_{z b}^{D}$ が底質の巻き上げ関数 $p_{N}$ に等しいとする条件 を用い，その $p_{N}$ として

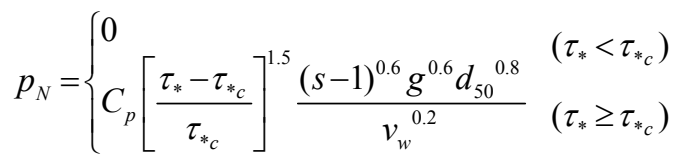

を用いた。 ここで， $C_{p}$ は底質の巻き上げに関する無 次元パラメータ, $s$ は底質の比重である.

\section{3. 計算条件}

図-1 に示寸名古屋港木場金岡尔頭 p-6 岸壁 (以降, 岸壁と称する）を対象に解析を行った. 図-2に計算 領域と現況の水深 $h$ の分布を示す. 地形デー夕は, 岸壁周辺では平成 21 年 1 月 24 日の深浅測量データ を, それ以外では平成 21 年 4 月に配布された海上保 安庁の水深図データを用いて作成した。 また, 対象 とした岸壁の南端に原点をとり,岸壁と法線 (東西) 方向に $x$ 軸，接線（南北）方向に $y$ 軸をとった. 図 -2 に示すように, この領域の北東側で水深が浅くな っていることから，これより東側の影響は小さいも のとみなし, $x$ 軸正方向には岸壁から東側へ $290.0 \mathrm{~m}$ の領域をとった。 また， $x$ 軸負方向には岸壁から西 側へ $190.0 \mathrm{~m}$ の領域をとった. 一方, $y$ 軸方向には岸 壁の南北端からそれぞれ $100.0 \mathrm{~m}$ の領域をとった. ただし, 計算領域の境界で地形が変化し, 計算が不 安定になるのを避けるために, $y$ 軸方向にさらにそ れぞれ $50.0 \mathrm{~m}$ の領域を設けた. なお，この領域では 地形変化は生じないものとし, 水深 $h$ は $y$ 軸方向に 一定とした. 最後に, $z$ 軸方向の計算領域は, 静水

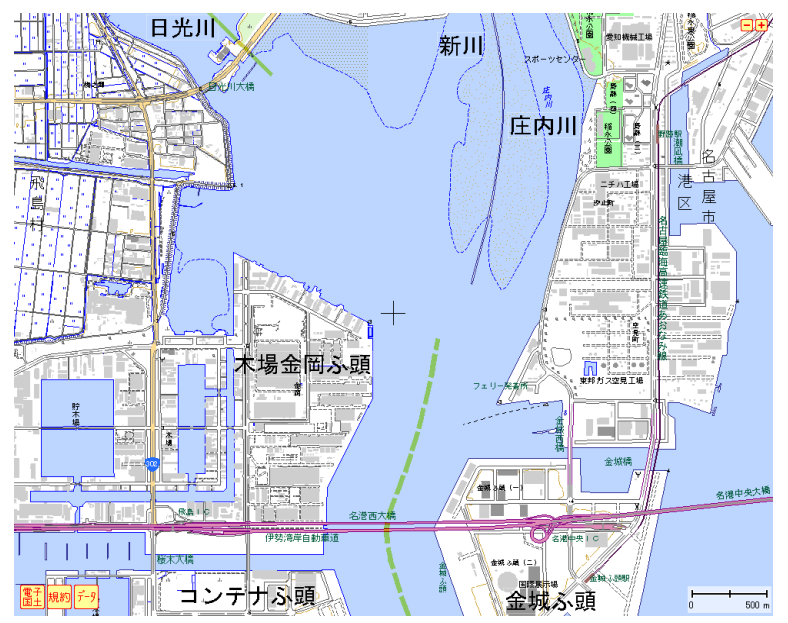

図-1 名古屋港木場金岡ふ頭
面から下側に $10.0 \mathrm{~m}$ ，上側に $3.0 \mathrm{~m}$ とした.

計算格子は, $x, y, z$ 軸方向にそれぞれ 10.0, 10.0, $0.50 \mathrm{~m}$ の等間隔格子とした。 また，現地を想定して 底質の中央粒径を $d_{50}=0.1 \mathrm{~mm}$, 空隙率を 0.4 , 密度 を $2.65 \times 10^{3} \mathrm{~kg} / \mathrm{m}^{3}$ とした。他のパラメータについて は, 中村・水谷 ${ }^{1)}$ を参照されたい.

平成 20 年 5 月の海上保安庁の海図より, コンテナ ふ頭と金城ふ頭の間の水域における大潮時の上げ潮 流と下げ潮流の最強流速はそれぞれ $0.10 \mathrm{~m} / \mathrm{s} \quad(0.2$ $\mathrm{kn}), 0.30 \mathrm{~m} / \mathrm{s}(0.6 \mathrm{kn})$ であることから，この海域で の地形変化は下げ潮時の方が卓越すると考えられる. そこで, 岸壁周辺での土砂堆積傾向が最も顕著に現 れると考えられる大潮の下げ潮時を対象とし, 計算 領域の北側（以下，上流側と称する）境界からの流 入流速として $0.30 \mathrm{~m} / \mathrm{s}$ を全断面に一様に与えた. た だし, 空気層の流入流速はゼロとした。また，南側

（以下，下流側と称寸る）境界には勾配ゼロの条件 を，岸壁表面，東側境界，西側境界，下側境界には Slip 条件を, 上側境界には圧力一定の条件を与えた.

計算領域の上流側境界からの土砂供給量について は, 日光川と新川のデータが得られなかったことか ら, 庄内川からの年間土砂供給量を基に設定した。 すなわち, 庄内川からの年間土砂供給量 30 万 $\mathrm{m}^{3}$ と 上述した流入流速 $0.30 \mathrm{~m} / \mathrm{s}$ に基づいて，上流端の格 子の浮遊砂濃度を指数関数分布に従って設定した. なお, 下流側境界には勾配ゼロの条件を, 岸壁表面, 東側境界，西側境界には不透過条件を課した。

\section{4. 現況地形での土砂堆積傾向}

本章では，数值計算モデルの再現性を検討するた めに, 図-2 に示した現況地形に対する計算を行う. 図-3に計算開始 1 時間後の地形変化量 $z_{s}$, , 図-4 に深浅測量データから算出した平成 16 年 12 月から 平成 21 年 1 月までの地形変化量 $z_{s}$ を示す.ここで, 正の $z_{s}$ は堆積を, 負の $z_{s}$ は侵食を示しており, 等深 線は計算開始前の初期の地形を表している。 また, 図-3 (a)には底面近傍での平均流速も示した。

図-3(a)より，岸壁の上流側隅角部 $(x=0 \mathrm{~m}, y=$ $480 \mathrm{~m}$ 付近）とそのすぐ下流側 $(50<x<100 \mathrm{~m}, 300$ $<y<450 \mathrm{~m})$ では侵食が, さらにその下流側 $(x>100$ $\mathrm{m},-50<y<150 \mathrm{~m})$ では堆積が生じていることが確 認できる. また, 図-3(b)に示した岸壁の周辺につい ては, $y=230 \mathrm{~m}$ 付近に侵食が認められるものの, 全 体的には堆積の傾向を示していることが確認できる. 一方，図-4に示した深浅測量データは，入手可能な データが限られていることから対象期間が約 4 年間 と長く，また $110<x<150 \mathrm{~m}$ の洗掘のように船舶の スクリューによる影響も確認できることから直接の 比較はできないものの, 岸壁の周辺では全体的に堆 積傾向を示している点で図-3(b) と図-4 は対応が認 


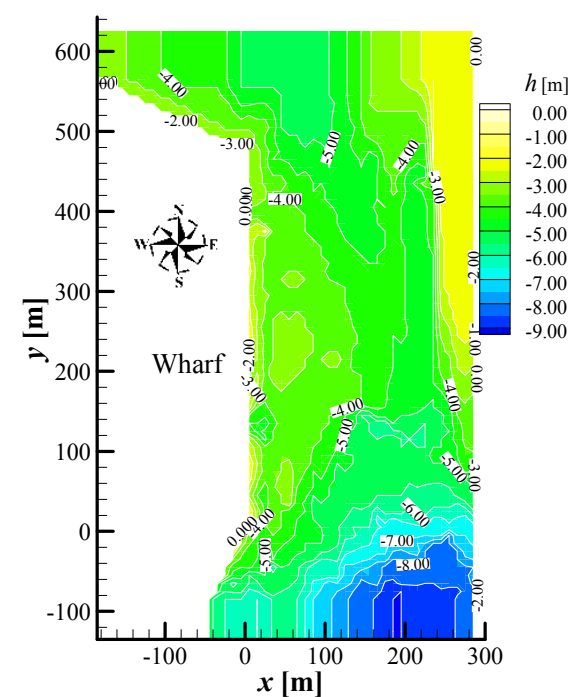

図-2 計算領域と現況の水深分布
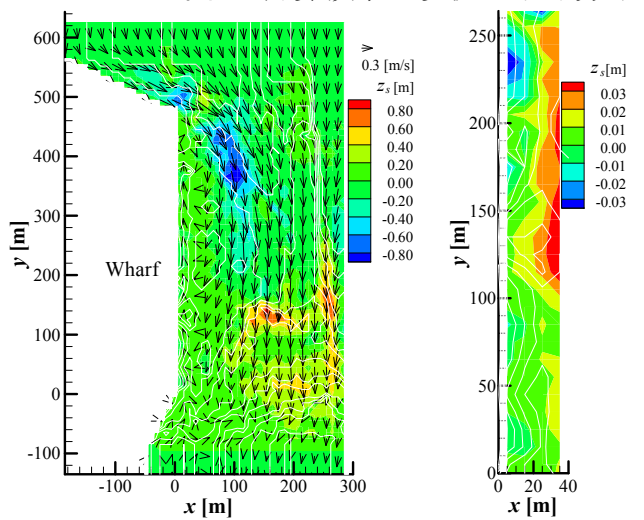

(a) 領域全体

（b）岸壁周辺

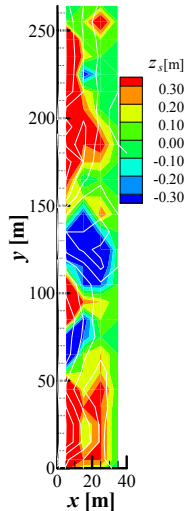

図-3 現況地形に対寸る地形変化量 $z_{s}$

\section{5. 浚渫時の土砂堆積傾向と効果的な浚渫範囲}

本章では, 浚渫範囲の違いによる土砂堆積傾向の 特性を明らかにするとともに，その結果に基づいて 効果的な浚渫範囲の検討を行う。

バースの利用に支障を来さないように，図-5(a) に示すように，図-2 の現況地形において岸壁下流部 の $0<x<50 \mathrm{~m}, y<210 \mathrm{~m}$ の範囲で水深 $6.0 \mathrm{~m}$ とし, その周辺は現況地形々勾配 $1 / 20$ の一様斜面で接続 した（以下，基準ケースと称する）。また，浚渫範囲 の違いによる影響を検討するために，浚渫範囲を基 準ケース $(y<210 \mathrm{~m})$ から上流側へ $50 \mathrm{~m}(y<260 \mathrm{~m})$ あるいは $100 \mathrm{~m} （ y<310 \mathrm{~m})$ 広げた場合も含めた 3 パターン, 浚渫範囲周辺の一様斜面を $1 / 20$ に加えて $1 / 40$ の場合も含めた 2 パターンとし, 計 6 種類の地 形を対象に解析を行った. 図-5に勾配 1/20 のとき の浚渫後の水深分布を示す.

\section{（1）浚渫範囲の違いが土砂堆積傾向に与える影響}

図-6に勾配 1/20 での計算開始 1 時間後の地形変 化量 $z_{s}$ と底面近傍での平均流速を示す。ただし，長 期間を対象とした計算は現時点では計算所要時間の 観点から現実的ではないことから，本論では図-6に 示したように計算開始初期の地形変化を対象とした。

図-6より, 浚渫前と地形が変わらない場所では, 浚渫の広さに関わらず, 図-3に示した現況地形の場 合と比較して, 底面近傍での平均流速の差があまり 認められないことが分かる，また，そのために，図 -3に示した現況地形に対する $z_{s}$ と同様に, 岸壁の上 流側隅角部とそのすぐ下流側では侵食が，さらにそ の下流側では堆積が生じていることが確認できる.

その一方で，浚渫で地形が変わった場所では，図 -6 の岸壁周辺を拡大した図-7より, 浚渫の広さによ って土砂の堆積傾向が異なることが確認できる。す なわち，地形変化が比較的大きい計算開始後 100 秒

モデルにより再現できることが確認できた。

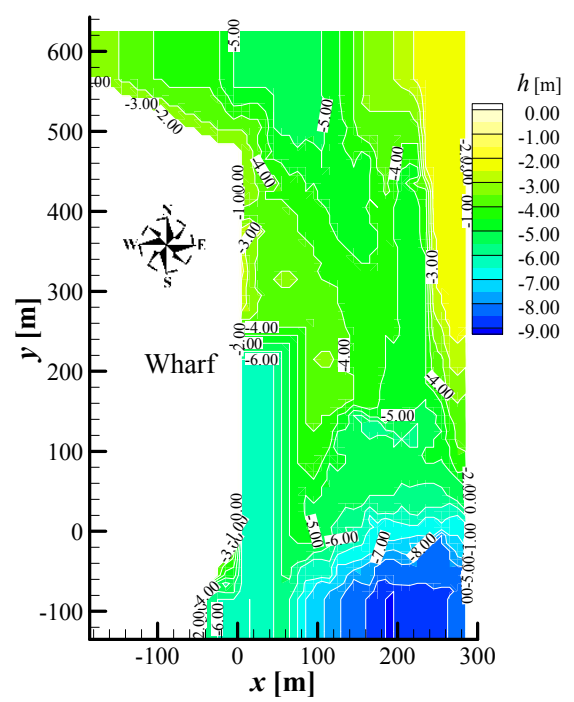

（a）浚渫範囲 $y<210 \mathrm{~m}$ （基準ケース）

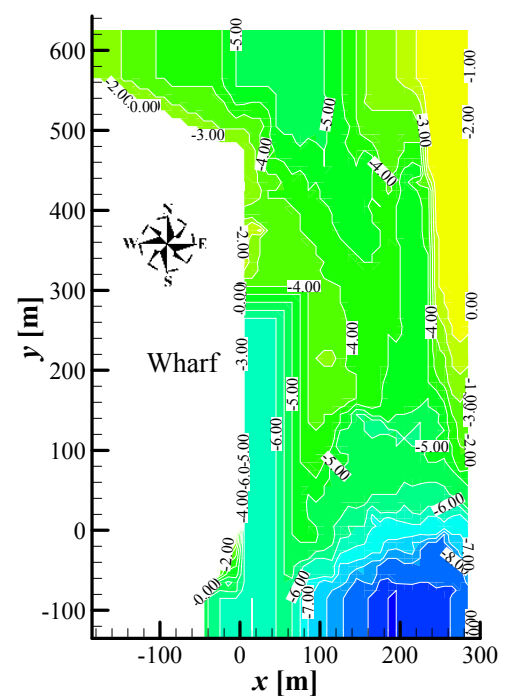

(b) 浚渫範囲 $y<260 \mathrm{~m}$

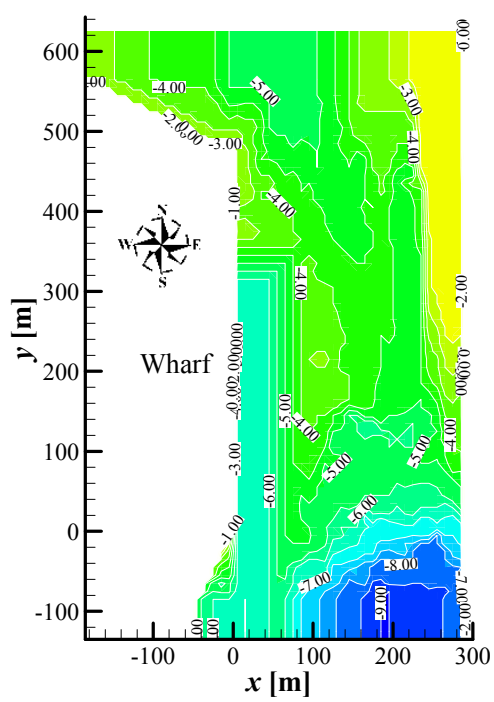

（c）浚渫範囲 $y<310 \mathrm{~m}$

図-5 浚渫時の水深分布（勾配 1/20) 
後の地形変化量 $z_{s}$ と底面近傍での流速を示した図-8 より，浚渫範囲が $y<210 \mathrm{~m}$ （図-8 (a)） と $y<260 \mathrm{~m}$

(図-8 (b)) のケースでは, $50<x<80 \mathrm{~m}, 80<y<150$ $\mathrm{m}$ に南西方向の流れが生じており, その下流側の水 深 $6.0 \mathrm{~m}$ の範囲では南西方向から南方向の流れが生 じていることが分かる，そのために，図-7(a)，(b) に示寸ように，浚渫範囲に流れ込んだ土砂が若干南 側に運ばれ，浚渫範囲の中流部 $(30<y<120 \mathrm{~m})$ で 土砂の堆積が生じたと考えられる。一方, 図-8(c) に示した浚渫範囲が $y<310 \mathrm{~m}$ のケースでは, 浚渫 範囲の北側にある水深の浅い部分を越えた流れが $50<x<80 \mathrm{~m}, 270<y<350 \mathrm{~m}$ で南西に向いているが, その位置が浚渫範囲周辺の一様斜面部と一致してい ることが分かる．また，このように浚渫範囲の上流 側からも流入しや寸くなったことから，水深 $6.0 \mathrm{~m}$ の範囲の上流部 $(250<y<300 \mathrm{~m})$ でも大きな流速 が生じていることが確認できる. そのために, 図 -7 (c) に示すように, 浚渫範囲の中流部だけではなく 上流部も含めた広い範囲 $(80<y<300 \mathrm{~m})$ で堆積が 生じていることが確認できる。一方, 勾配 $1 / 40$ のと
きの地形変化量 $z_{s}$ を示した図-9より, 土砂の堆積が 生じる位置は図-7 に示した勾配 1/20 の場合とほと んど変わらないものの, 浚渫範囲 $y<210 \mathrm{~m}$ と $y<260$ $\mathrm{m}$ のケースでは土砂の堆積がより広い範囲で生じて いることが確認できる.

以上より, 浚渫範囲の土砂堆積傾向は浚渫の広さ やその周辺の勾配によって異なり，浚渫範囲をある 程度よりも上流側に広げると，その北側にある水深 の浅い部分を越えた流れが直接流入しや寸くなるこ とから, 浚渫範囲の中流部に加えて上流部でも堆積 が生じることが明らかとなった。

\section{（2）土砂堆積傾向に基づく効果的な浚渫範囲の検討}

浚渫範囲での土砂の堆積は上述したように勾配 $1 / 20$ の方が狭い範囲で生じていたことから，ここで は勾配 1/20のケースに着目し，バースの利用に支障 を来さないように $0<x<50 \mathrm{~m}, y<210 \mathrm{~m}$ において 土砂の堆積が抑えられる浚渫範囲の検討を行う。

図-10に，勾配 $1 / 20$ での計算開始 1 時間後の地形 変化量 $z_{s}$ に関して, 浚渫範囲 $y<210 \mathrm{~m}$ との差を図

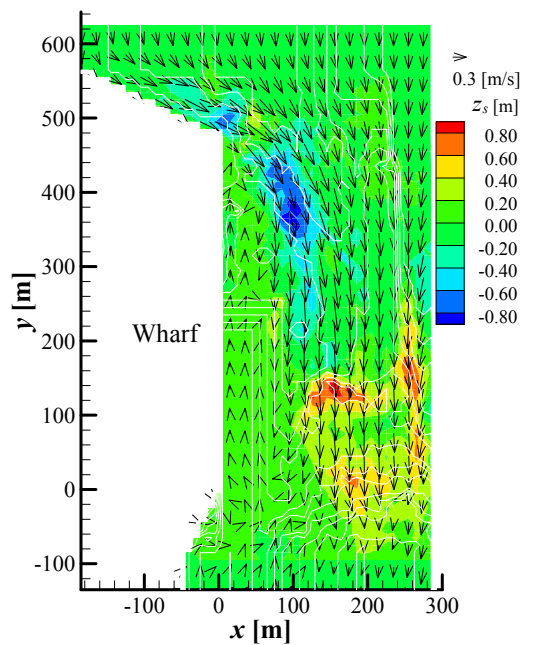

（a）浚渫範囲 $y<210 \mathrm{~m}$ （基準ケース）

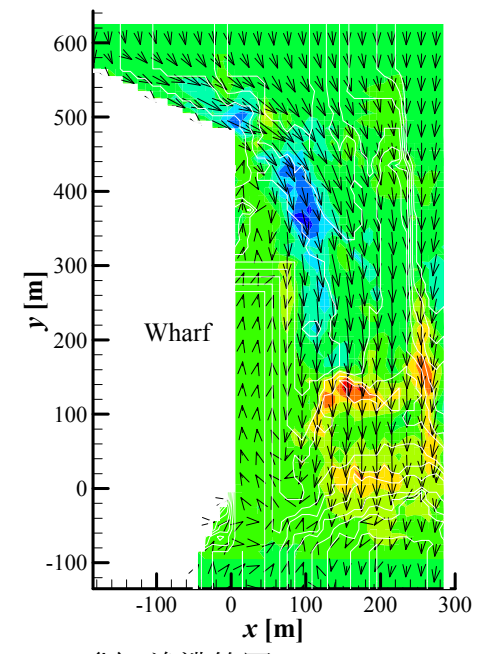

(b) 浚渫範囲 $y<260 \mathrm{~m}$

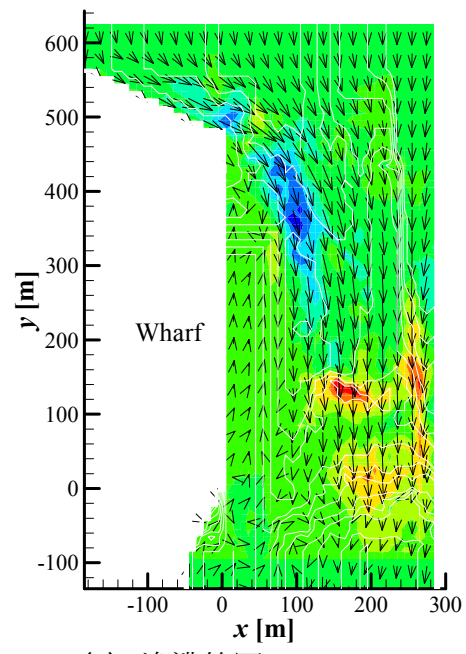

(c) 浚渫範囲 $y<310 \mathrm{~m}$

図-6 浚渫時の地形変化量 $z_{s}$ と底面近傍での平均流速（勾配 $1 / 20$ )

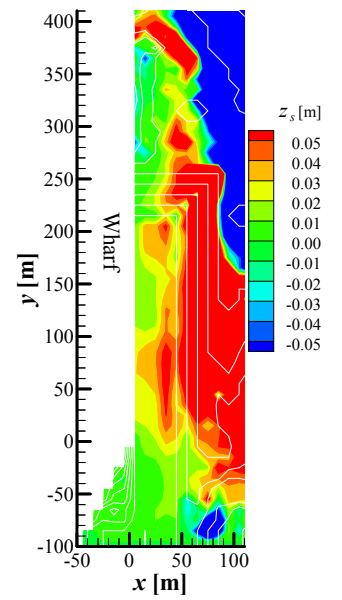

(a) 浚渫範囲 $y<210 \mathrm{~m}$ (基準ケース)

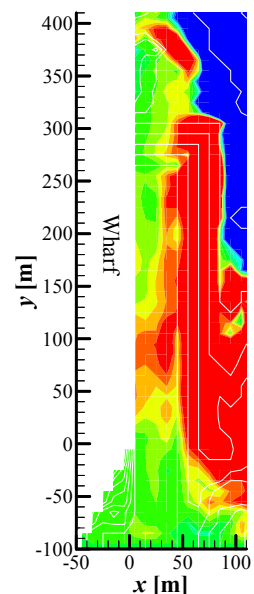

(b) 浚渫範囲 $y<260 \mathrm{~m}$

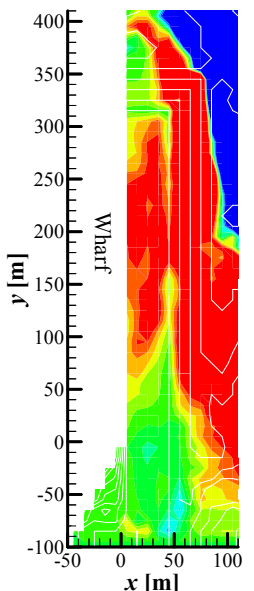

(c) 浚渫範囲 $y<310 \mathrm{~m}$

図-7 浚渫時の岸壁周辺での地形変化量 $z_{s}$ (勾配 $1 / 20$ )

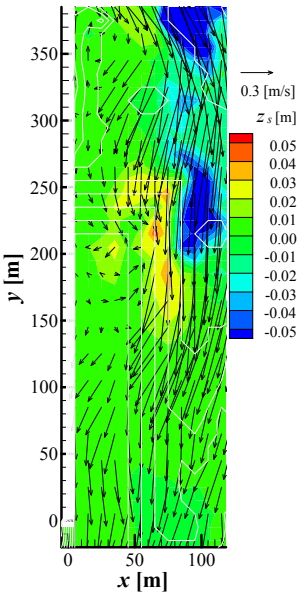

(a) 浚渫範囲 $y<210 \mathrm{~m}$ (基準ケース)

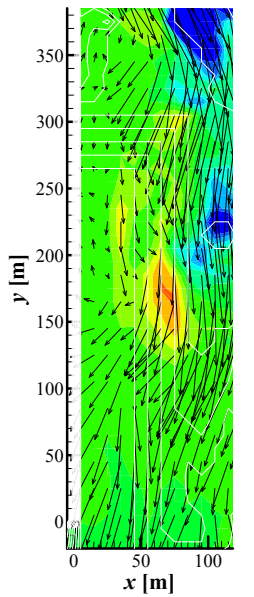

(b) 浚渫範囲 $y<260 \mathrm{~m}$

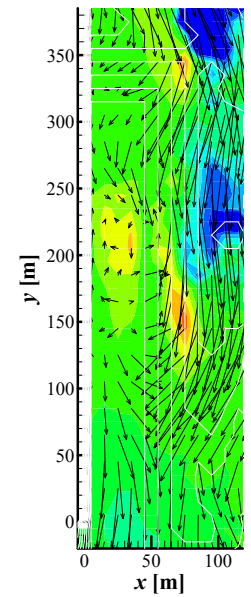

(c) 浚渫範囲 $y<310 \mathrm{~m}$

図-8 浚渫時の岸壁周辺の底面近傍流速 (勾配 $1 / 20$, 計算開始 100 秒後) 


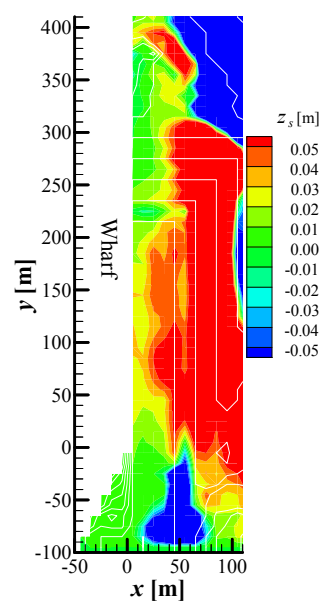

(a) 浚渫範囲 $y<210 \mathrm{~m}$ (基準ケース) 図-9 浚渫時の岸壁周辺での地形変化量

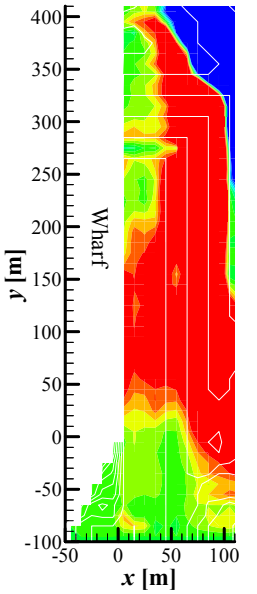

(b) 浚渫範囲 $y<260 \mathrm{~m}$

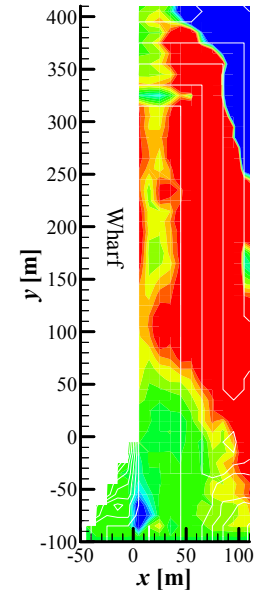

(c) 浚渫範囲 $y<310 \mathrm{~m}$

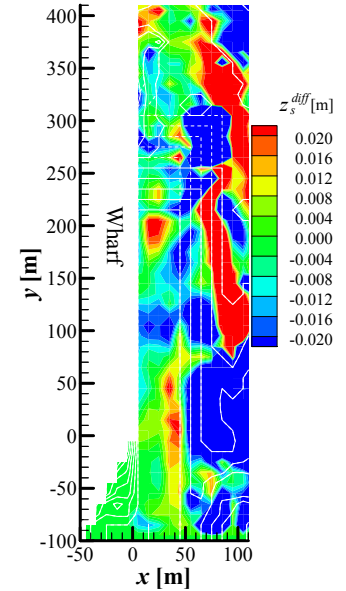

(a) 浚渫範囲 $y<260 \mathrm{~m}$

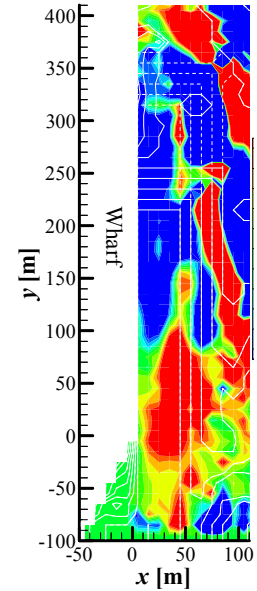

(b) 浚渫範囲 $y<310 \mathrm{~m}$

図-10 浚渫範囲 $y<210 \mathrm{~m}$ に対する岸壁周辺 での地形変化量の差 $z_{s}^{\text {diff (勾配 1/20) }}$

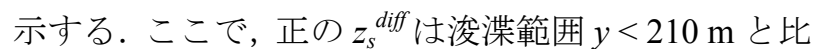
較して土砂の堆積が生じやすくなったことを表す.

まず浚渫範囲 $y<210 \mathrm{~m}$ と $y<260 \mathrm{~m}$ を比較した図 -10 (a) より, 浚渫範囲の中流部 $(80<y<130 \mathrm{~m})$ で

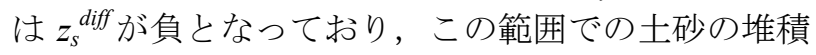
は浚渫範囲 $y<260 \mathrm{~m}$ の方が若干生じやすくなる傾 向が認められる.ただし, 上述したように, この付 近では船舶のスクリューの影響が強いことから，こ の堆積傾向の差はあまり問題にならないと考えられ る. その一方で, 浚渫範囲の上流部 $(170<y<210 \mathrm{~m})$

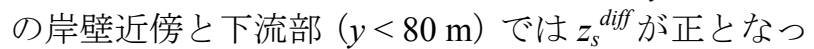
ており, 浚渫範囲を $y<260 \mathrm{~m}$ に広げることで土砂 の堆積が抑えられることが分かる.

次に, 浚渫範囲 $y<210 \mathrm{~m}$ と $y<310 \mathrm{~m}$ を比較した 図-10 (b) より, 浚渫範囲を $y<310 \mathrm{~m}$ とさらに広げ ると，その下流部 $(y<100 \mathrm{~m})$ では土砂の堆積が抑 えられることが分かる.しかし，上述したように， 水深の浅い部分を越えた流れが直接流入するように なることから, 浚渫範囲の上流部から中流部にかけ ての広い範囲 $(100<y<210 \mathrm{~m})$ で土砂の堆積が生 じや寸くなることが確認できる.

以上より, 基準となる浚渫範囲 $y<210 \mathrm{~m}$ から北 側に $50 \mathrm{~m}$ 広げることで土砂の堆積が最も抑えられ ることから, より長期に渡って必要な水深を確保で きると考えられ, 浚渫範囲 $y<260 \mathrm{~m}$ が浚渫を行う 範囲として最も効果的であると言える.

\section{6. 結論}

本研究では, 土砂の堆積により必要な水深の確保
が困難になっている現地の岸壁を対象に, 流動場と 地形変化の相互作用を解析できる 3 次元数值計算モ デルを用いて効果的な浚渫範囲の検討を行った。 そ の結果, 浚渫範囲の土砂堆積傾向は浚渫の広さやそ の周辺の勾配によって異なること, 流れが上流側か ら直接流入しない程度に浚渫範囲を上流側に広げた 場合に, より長期に渡って必要な水深を確保でき, 最も効果的であることを明らかにした．また，この ように浚渫範囲の土砂堆積傾向は地形の影響を大き く受けることから，流動場が地形変化に与える影響 だけではなく，地形変化が流動場に与える影響も考 慮することの重要性が確認できるとともに，効果的 な浚渫範囲を検討するツールとしての本数值計算モ デルの有用性が明らかとなった。

\section{参考文献}

1) 中村友昭, 水谷法美 : 3 次元流体・構造・地形変化連成 数值計算モデルに基づく遡上津波による陸上構造物周 辺の局所洗掘現象に関する数值シミュレーション, 第 24 回数值流体力学シンポジウム, E10-4, 9 p., 2010.

2) 功刀資彰 : 自由表面を含む多相流の直接数值解析法, 機械学会論文集 B編, 第 63 巻, 第 609 号, pp. 1576-1584. 1997.

3)水谷法美, 前田健一郎, Ayman M. Mostafa, William G. McDougal : 透水性構造物の抵抗係数の評価と波・潜水 透水性構造物の非線形相互作用の数值解析, 海岸工学論 文集, 第 43 巻, pp. 131-135, 1996.

4) Roulund, A., Sumer, B. M., Fredsøe, J., and Michelsen, J.: Numerical and experimental investigation of flow and scour around a circular pile, J. Fluid Mech., Vol. 534, pp. 351-401, 2005.

5) Nielsen, P., Svendsen, I. A., and Staub, C.: Onshore- offshore sediment movement on a beach, Proc., Int. Conf. on Coastal Eng., ASCE, Vol. 16, pp. 1475-1492, 1992. 